\title{
Identification of cardioprotective agents from traditional Chinese medicine against oxidative damage
}

\author{
JIAN-MING ZHOU, ZHI-LIANG XU, NA LI, YI-WU ZHAO, ZHEN-ZHONG WANG and WEI XIAO
}

\author{
State Key Laboratory of New-Tech for Chinese Medicine Pharmaceutical Process, \\ Jiangsu Kanion Modern Traditional Chinese Medicine Research Institute, Lianyungang, Jiangsu 222001, P.R. China
}

Received June 11, 2015; Accepted February 23, 2016

DOI: $10.3892 / \mathrm{mmr} .2016 .5243$

\begin{abstract}
Reactive oxygen species are damaging to cardiomyocytes. H9c2 cardiomyocytes are commonly used to study the cellular mechanisms and signal transduction in cardiomyocytes, and to evaluate the cardioprotective effects of drugs following oxidative damage. The present study developed a robust, automated high throughput screening (HTS) assay to identify cardioprotective agents from a traditional Chinese medicine (TCM) library using a $\mathrm{H}_{2} \mathrm{O}_{2}$-induced oxidative damage model in H9c2 cells. Using this HTS format, several hits were identified as cardioprotective by detecting changes to cell viability using the cell counting kit (CCK)-8 assay. Two TCM extracts, KY-0520 and KY-0538, were further investigated. The results of the present study demonstrated that treatment of oxidatively damaged cells with KY-0520 or KY-0538 markedly increased the cell viability and superoxide dismutase activity, decreased lactate dehydrogenase activity and malondialdehyde levels, and inhibited early growth response-1 (Egr-1) protein expression. The present study also demonstrated that KY-0520 or KY-0538 treatment protected $\mathrm{H} 9 \mathrm{c} 2$ cells from $\mathrm{H}_{2} \mathrm{O}_{2}$-induced apoptosis by altering the $\mathrm{Bcl}-2 / \mathrm{Bax}$ protein expression ratio, and decreasing the levels of cleaved caspase-3. In addition, KY-0520 and KY-0538 reduced the phosphorylation of ERK1/2 and p38-MAPK proteins, and inhibited the translocation of Egr-1 from the cytoplasm to nucleus in $\mathrm{H}_{2} \mathrm{O}_{2}$-treated $\mathrm{H} 9 \mathrm{c} 2$ cells. These findings suggested that oxidatively damaged $\mathrm{H} 9 \mathrm{c} 2$ cells can be used for the identification of cardioprotective agents that reduce oxidative stress by measuring cell viabilities using CCK-8 in an HTS format. The underlying mechanism of the cardioprotective activities of KY-0520 and KY-0538 may be attributed to their antioxidative activity, regulation of Egr-1 and apoptosis-associated proteins,
\end{abstract}

Correspondence to: Dr Wei Xiao, State Key Laboratory of New-Tech for Chinese Medicine Pharmaceutical Process, Jiangsu Kanion Modern Traditional Chinese Medicine Research Institute, 58 Kanion Road, Lianyungang, Jiangsu 222001, P.R. China E-mail: jianmin8920@163.com

Key words: oxidative stress, high throughput screening, traditional Chinese medicine and the inhibition of ERK1/2, p38-MAPK and Egr-1 signaling pathways.

\section{Introduction}

Oxidative stress is important in various disease processes, including in cancer, inflammation, cardiovascular diseases, atherosclerosis, central nervous system disorders, neurodegenerative diseases, diabetes and respiratory diseases. Almost all human organs can be damaged by oxidative stress (1-5). In the cardiovascular system, reactive oxygen species (ROS) induce the oxidation of low density lipoprotein, cholesterol, cholesterol-derived species and protein modifications, which can lead to foam cell formation, atherosclerotic plaques and vascular thrombosis (6). Various studies have previously demonstrated that cardiomyocyte damage induced by heart ischemia/reperfusion is predominantly due to the generation of ROS (7-9). Other studies also indicated that ROS can damage the sarcoplasmic reticulum of cardiac cells, inducing contractile dysfunction and $\mathrm{Ca}^{2+}$ release by modifying the structure and function of cardiac proteins, which may be important in the formation of myocardial ischemia/reperfusion injury $(9,10)$. Several investigations have demonstrated that ROS induce cardiomyocyte apoptosis by activating various signaling pathways, including mitogen-activated protein kinase 14 (p38MAPK), MAPK 1 (also known as ERK1/2), MAPK 8 (also known as JNK) and v-akt murine thymoma viral oncogene homolog 1 (Akt1) signaling, which may contribute to the development and progression of cardiac dysfunction and heart failure (11-13). Additionally, angiotensin II stimulates ROS-mediated activation of the transcription factor nuclear factor- $\kappa \mathrm{B}$, which is understood to be involved in the induction of cardiac hypertrophy. ROS also regulates the transcription of jun proto-oncogene, which influences the expression of other genes in cardiac hypertrophy (14). In summary, oxidative stress participates in a variety of pathological mechanisms associated with cardiomyocyte diseases.

Numerous in vitro studies of oxidative stress in cardiomyocytes have been performed using H9c2 cardiomyocytes. $\mathrm{H} 9 \mathrm{c} 2$ cells are a clonal cardiomyocyte cell line derived from embryonic rat ventricles (15), with a similar profile of signaling mechanisms to adult cardiomyocytes. Under oxidative stress, $\mathrm{H} 9 \mathrm{c} 2$ cardiomyocytes respond in a similar manner to myocytes in primary cultures or isolated heart experiments (16). H9c2 
cells have been demonstrated to be a useful tool for the study of the cellular mechanisms and signal transduction pathways of cardiomyocytes (17-20).

$\mathrm{H}_{2} \mathrm{O}_{2}$-treated $\mathrm{H} 9 \mathrm{c} 2$ cells have been commonly used as an in vitro model for studying oxidative stress in cardiomyocytes, and to evaluate the cardioprotective effects of drugs against oxidative damage (21-24). However, to the best of our knowledge, H9c2 cells have not been previously used for high-throughput drug screening. The current study used this model to establish a cell-based screening assay in a high throughput format. From a library of traditional Chinese medicine (TCM) extracts, 17 primary hits were identified, 2 of which were further validated as cardioprotective agents against oxidative damage. The present study demonstrated the used of the $\mathrm{H}_{2} \mathrm{O}_{2}$-induced cell damage model in a high-throughput screening (HTS) assay, which may be established as an efficient and low-cost HTS assay for the identification of candidate drugs that reduce oxidative damage from large TCM extract/chemical libraries.

\section{Materials and methods}

Cell culture. H9c2 cells (Cell Resource Centre of the Shanghai Institutes for Biological Sciences, Chinese Academy of Science, Shanghai, China) were maintained in Dulbecco's modified Eagle's medium (Gibco; Thermo Fisher Scientific, Inc., Waltham, MA, USA) containing 10\% FBS (Gibco; Thermo Fisher Scientific, Inc.) and incubated at $37^{\circ} \mathrm{C}$ in a humid atmosphere of $5 \% \mathrm{CO}_{2}$. Following expansion, cells at passage 3 were used for all experiments.

Cell counting kit (CCK)-8 assays. H9c2 cells were used to establish the cell model of oxidative damage. H9c2 cells (100 $\mu \mathrm{l} /$ well) were seeded into 96 -well plate at a density of $3.0 \times 10^{4}$ cells $/ \mathrm{ml}$ and incubated at $37^{\circ} \mathrm{C}, 5 \% \mathrm{CO}_{2}$ overnight. The cells were then treated with $100 \mu 150 \mu \mathrm{mol} / 1 \mathrm{H}_{2} \mathrm{O}_{2}$ (Shandong Siqiang Chemical Group Co., Ltd., Liaocheng, China) for 3 h. Following $\mathrm{H}_{2} \mathrm{O}_{2}$ treatment, a CCK-8 assay kit (BestBio, Shanghai, China) was used to detect cell viabilities according to the manufacturer's instructions. In brief, following treatment with $\mathrm{H}_{2} \mathrm{O}_{2}, 10 \mu \mathrm{l}$ CCK-8 solution was added to each well. After 1-4 h incubation, cell viability was determined by measuring the absorbance at $450 \mathrm{~nm}$ using a Flex Station 3 microplate spectrophotometer (Molecular Devices, LLC, Sunnyvale, CA, USA).

For drug activity assays, $100 \mu \mathrm{l} \mathrm{H} 9 \mathrm{c} 2$ cells/well were seeded into 96 -well plates at a density of $3.0 \times 10^{4}$ cells $/ \mathrm{ml}$, and incubated overnight. Each plate contained 8 negative and 8 positive control wells, and all cells, excluding the positive controls, were treated with $100 \mu \mathrm{l} /$ well $\mathrm{H}_{2} \mathrm{O}_{2}(50 \mu \mathrm{mol} / \mathrm{l})$ for $3 \mathrm{~h}$. Following $\mathrm{H}_{2} \mathrm{O}_{2}$ treatment, $0.1 \mu \mathrm{l} /$ well dimethyl sulfoxide (DMSO; Sigma-Aldrich, St. Louis, MO, USA) was added to the positive control wells, and $0.1 \mu \mathrm{l} /$ well TCM extract samples were added to the all other wells, excluding the negative controls. Cells were then incubated for an additional $3 \mathrm{~h}$. Cell viabilities were tested using the CCK-8 assay kit to assess drug activities.

Lactate dehydrogenase ( $\mathrm{LDH}$ ) activity, malondialdehyde (MDA) content and superoxide dismutase (SOD) activity assays. LDH, MDA and SOD were measured using the respective assay kits (Beyotime Institute of Biotechnology, Haimen, China) according to the manufacturer's instructions. Briefly, 1,000 $\mu \mathrm{l} /$ well H9c2 cells were seeded into 24-well plates at a density of $3.0 \times 10^{4}$ cells $/ \mathrm{ml}$. Following a $3-\mathrm{h}$ treatment with $50 \mu \mathrm{mol} / 1 \mathrm{H}_{2} \mathrm{O}_{2}$, and a 3-h incubation with $50 \mu \mathrm{mol} / 1$ quercetin and $25 \mu \mathrm{g} / \mathrm{ml}$ TCM extracts, the cells were centrifuged at $400 \times \mathrm{g}$ for $5 \mathrm{~min}$, and $120 \mu \mathrm{l}$ of the supernatant was then transferred to a 96-well plate for LDH activity determination. Subsequently, all cells were lysed and centrifuged at $1,600 \mathrm{x} \mathrm{g}$ for $10 \mathrm{~min}$, the supernatants were then collected and stored at $-80^{\circ} \mathrm{C}$ prior to MDA and SOD detection.

For LDH assays, $60 \mu 1$ working solution, containing $20 \mu \mathrm{l}$ lactic acid solution, $20 \mu \mathrm{l} 1 \mathrm{X}$ INT solution and $20 \mu \mathrm{l}$ enzyme solution, was added to each sample (total, $180 \mu \mathrm{l}$ ) for an additional $30 \mathrm{~min}$ incubation by gently agitating at room temperature. The maximum LDH release of target cells was determined by lysing target cells for $45 \mathrm{~min}$ and subsequently measuring the LDH from the culture medium. Absorbance values after the colorimetric reaction were measured at $490 \mathrm{~nm}$ with a reference wavelength of $655 \mathrm{~nm}$, using a Flex Station 3 microplate spectrophotometer (Molecular Devices, LLC, Sunnyvale, CA, USA).

For MDA assays, $200 \mu \mathrm{l}$ working solution was added to $100 \mu \mathrm{l}$ samples for an additional $15 \mathrm{~min}$ incubation at $100^{\circ} \mathrm{C}$, and were subsequently centrifuged at $1,000 \mathrm{x} \mathrm{g}$ for $10 \mathrm{~min}$ after the samples cooled to room temperature. Subsequently, $200 \mu 1$ supernatant was transferred to a 96-well plate for MDA detection by Flex Station 3 microplate spectrophotometer at $532 \mathrm{~nm}$ absorbance with a reference wavelength of $450 \mathrm{~nm}$.

For SOD assays, $180 \mu \mathrm{l}$ working solution was added to $20 \mu \mathrm{l}$ sample for an additional $30 \mathrm{~min}$ incubation at $37^{\circ} \mathrm{C}$. SOD activities were detected at $490 \mathrm{~nm}$ with a reference wavelength of $600 \mathrm{~nm}$, using the same microplate reader as before.

Western blotting. The protein expression levels of the apoptotic proteins, caspase-3, B-cell CLL/lymphoma 2 (Bcl-2), Bcl-2-associated X protein (Bax), and the MAPK subfamily proteins, p38, JNK and ERK1/2, were detected by western blotting. A total of $1.5 \times 10^{6}$ cells $/ \mathrm{ml} /$ well were seeded into 6 -well plates. Following $3 \mathrm{~h}$ treatment with $12.5 \mu \mathrm{mol} / \mathrm{l}$ (for MAPK proteins) or $50 \mu \mathrm{mol} / 1$ (for apoptotic proteins) $\mathrm{H}_{2} \mathrm{O}_{2}$, cells were incubated with $25 \mu \mathrm{g} / \mathrm{ml}$ active extracts for $3 \mathrm{~h}$. The cells were then rinsed twice with ice-cold $1 \mathrm{X}$ phosphate-buffered saline (PBS) and harvested under non-denaturing conditions by incubation at $4^{\circ} \mathrm{C}$ with lysis buffer (Qiagen, Hilden, Germany) containing protease and phosphorylase inhibitors for $10 \mathrm{~min}$. The cell lysates were centrifuged at $14,000 \mathrm{x} \mathrm{g}$ for $10 \mathrm{~min}$ at $4^{\circ} \mathrm{C}$ to remove insoluble precipitates. The protein content in each sample was determined by Bradford assay (Applygen Technologies, Inc., Beijing, China). Total protein $(50 \mu \mathrm{g})$ from cell culture samples was denatured and separated by SDS-PAGE on $12 \%$ acrylamide gels, and subsequently electrophoretically transferred to polyvinylidene fluoride membranes. Nonspecific binding sites were blocked by incubation of membranes in Tris-buffered saline with Tween (TBS-T) containing 5\% bovine serum albumin (BSA; Amresco, LLC, Solon, OH, USA) for $2 \mathrm{~h}$. The membranes 
A

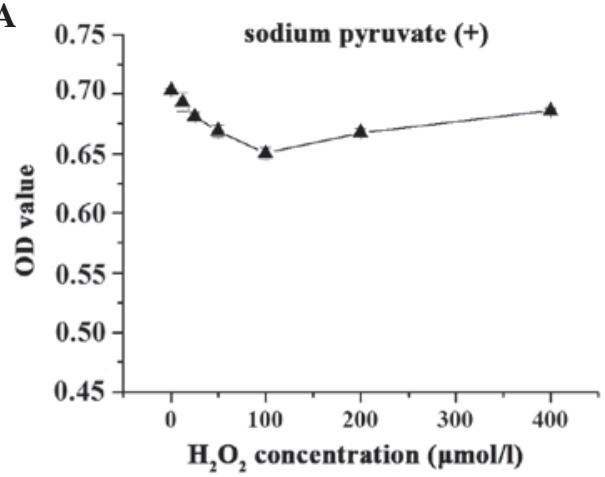

C

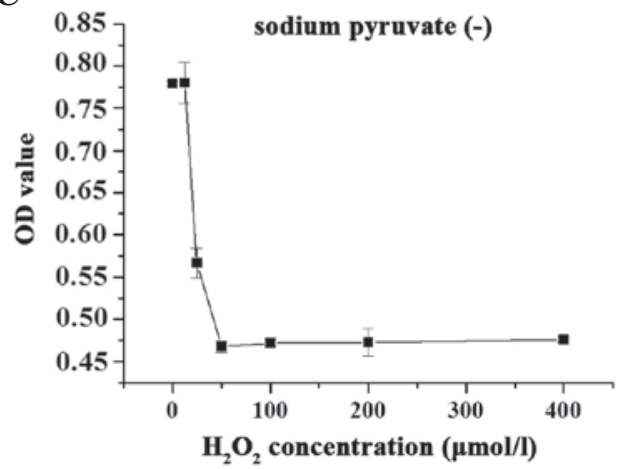

B

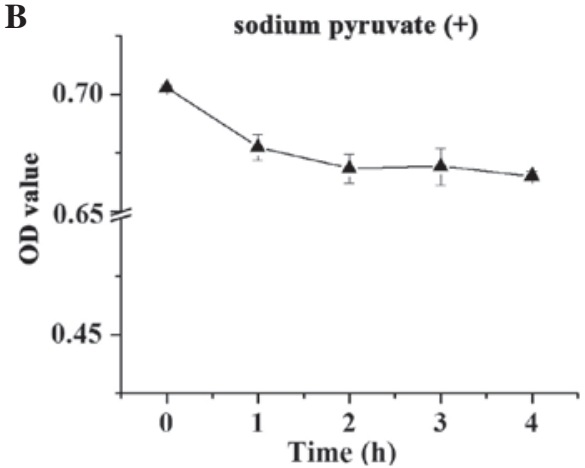

D

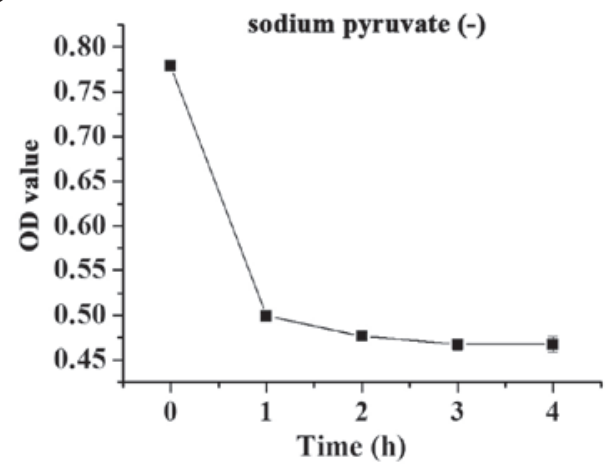

Figure 1. Effect of different concentrations and incubation times of $\mathrm{H}_{2} \mathrm{O}_{2}$ on the viability of $\mathrm{H} 9 \mathrm{c} 2 \mathrm{cells}$. $\mathrm{H} 9 \mathrm{c} 2 \mathrm{cells}(100 \mu \mathrm{l} / \mathrm{well})$ at a density of $3.0 \mathrm{x} 10^{4}$ cells $/ \mu 1$ were treated with different concentrations $(0-400 \mu \mathrm{mol} / 1)$ of $\mathrm{H}_{2} \mathrm{O}_{2}$ at $37^{\circ} \mathrm{C}$ and $5 \% \mathrm{CO}_{2}$ for $0-4$ h. Cell viabilities were then analyzed using cell counting kit- 8 assay with absorbance measured at $450 \mathrm{~nm}$. H9c2 cells incubated in medium supplemented with $110 \mathrm{mg} / \mathrm{ml} \mathrm{sodium}$ pyruvate were treated with (A) different concentrations of $\mathrm{H}_{2} \mathrm{O}_{2}$ for $4 \mathrm{~h}$ and (B) $50 \mu \mathrm{mol} / 1 \mathrm{H}_{2} \mathrm{O}_{2}$ for different time periods. $\mathrm{H} 9 \mathrm{c} 2$ cells incubated in sodium pyruvate-free medium were treated with (C) different concentrations of $\mathrm{H}_{2} \mathrm{O}_{2}$ for $4 \mathrm{~h}$ and (D) $50 \mu \mathrm{mol} / 1 \mathrm{H}_{2} \mathrm{O}_{2}$ for different time periods. OD, optical density.

were then incubated with primary antibodies against rabbit anti-caspase-3 (cat. no. sc-7148; Santa Cruz Biotechnology, Inc., Santa Cruz, CA, USA), rabbit anti-Bcl-2 (cat. no. 2870 S Cell Signaling Technology, Inc., Danvers, MA, USA), rabbit anti-Bax (cat. no. sc-526; Santa Cruz Biotechnology, Inc.), rabbit anti-p38 (cat. no. 9212; Cell Signaling Technology, Inc.), rabbit anti-phospho (p)-p38 (cat. no. 4631; Cell Signaling Technology, Inc.), rabbit-anti-JNK (cat. no. 9258; Cell Signaling Technology, Inc.), rabbit anti-p-JNK (cat. no. 4671; Cell Signaling Technology, Inc.), rabbit anti-ERK1/2 (cat. no. 9102S; Cell Signaling Technology, Inc.), rabbit anti-p-ERK1/2 (cat. no. 9101S; Cell Signaling Technology, Inc.) all at 1:1,000 dilution, overnight at $4^{\circ} \mathrm{C}$. The membranes were washed with TBS-T and were subsequently incubated with horseradish peroxidase-conjugated goat anti-rabbit secondary antibody (cat. no. 7074; 1:2,000; Cell Signaling Technology, Inc.) for $2 \mathrm{~h}$ and visualized using a Chemi Doc XRS+ detection system (Bio-Rad Laboratories, Inc., Hercules, CA, USA). $\beta$-tubulin was used as a loading control.

Immunofluorescence assays for early growth response-1 (Egr-1). H9c2 cells (100 $\mu \mathrm{l} / \mathrm{well})$ at a density of $5.0 \times 10^{4}$ cells $/ \mathrm{ml}$ were seeded into 96 -well plates. The cells were untreated (control) or incubated with 12.5 or $200 \mu \mathrm{mol} / 1 \mathrm{H}_{2} \mathrm{O}_{2}$ alone, or with $12.5 \mu \mathrm{mol} / 1 \mathrm{H}_{2} \mathrm{O}_{2}$ and $25 \mu \mathrm{g} / \mathrm{ml}$ active extracts for $2 \mathrm{~h}$. Subsequently, the cells were fixed with $4 \%$ (v/v) formaldehyde (Amresco, LLC) in 1X PBS at room temperature for
15 min, then washed with 1X PBS 3 times, and blocked with $1 \%(\mathrm{w} / \mathrm{v}) \mathrm{BSA}$ (Amresco, LLC) in $1 \mathrm{X}$ PBS containing $0.3 \%$ (v/v) Triton X-100 (Amresco, LLC) at room temperature for 30 min. The primary antibody against Egr-1 (cat. no. sc-110; 1:100; Santa Cruz Biotechnology, Inc.) was incubated with the cells at $37^{\circ} \mathrm{C}$ for $2 \mathrm{~h}$. Subsequently, cells were washed with PBS and incubated with goat anti-rabbit IgG-CruzFluor 488 (cat. no. sc-362262; 1:250; Santa Cruz Biotechnology, Inc.) at $37^{\circ} \mathrm{C}$ for $1 \mathrm{~h}$. Following 3 washes with $1 \mathrm{X}$ PBS, cell nuclei were stained using Hoechst 33258 (Sigma-Aldrich) at a final concentration of $2 \mu \mathrm{g} / \mathrm{ml}$ for $15 \mathrm{~min}$. Fluorescent images were captured using a DMI 4000B fluorescence microscope (Leica Microsystems GmbH, Wetzlar, Germany).

The library of TCM extracts. Each TCM herb (500 g) was soaked in water for $1 \mathrm{~h}$ prior to extraction, and extraction was performed twice by boiling in 10- and 8-fold volumes of water (v/v) for 2 h. Extracts were filtered through gauze, and all crude extractions were combined and concentrated to $500 \mathrm{ml}$. The concentrates were then separated on macroporous resins (specification, $\Phi 5 \times 60 \mathrm{~cm}$; 1:1 weight ratio of the concentrates; HaiGuang Chemical Co., Ltd., China) by successive elution with water and different concentration gradients of ethanol (20-95\%), with 3 bed volumes (BV) of eluent volume at a flow rate of $1 \mathrm{BV} / \mathrm{h}$. Eight samples from each TCM herb were collected, and concentrated at $70^{\circ} \mathrm{C}$. Following freeze drying, $5 \mathrm{mg}$ of each sample was dissolved into $200 \mu \mathrm{l} \mathrm{DMSO}$, then dispensed into 96 -well plates. 


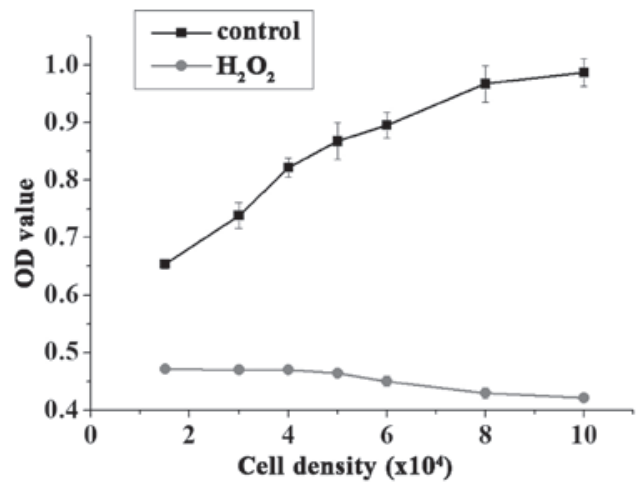

Figure 2. Effects of cell density on the viability of $\mathrm{H}_{2} \mathrm{O}_{2}$-treated $\mathrm{H} 9 \mathrm{c} 2$ cells. H9c2 cells $(100 \mu 1 /$ well $)$ at the densities of $1.5,3.0,4.0,5.0,6.0,8.0$ and $10 \times 10^{4}$ cells $/ \mathrm{ml}$ were seeded into $96-$ well plates. The cells were treated with $50 \mu \mathrm{mol} / 1 \mathrm{H}_{2} \mathrm{O}_{2}$ at $37^{\circ} \mathrm{C}$ and $5 \% \mathrm{CO}_{2}$ for $3 \mathrm{~h}$, and cell viabilities were then assessed using cell counting kit- 8 assay, measuring absorbance at $450 \mathrm{~nm}$. OD, optical density.

Statistical analysis. All data are presented as the mean \pm standard deviation (SD). Statistical analysis was performed using one-way analysis of variance and Tukey's post-hoc tests using SPSS software version 17.0 (SPSS, Inc., Chicago, IL, USA). $\mathrm{P}<0.05$ was considered to indicate a statistically significant difference.

\section{Results}

Creation and optimization of oxidative damage cell model for HTS.

To establish a stable HTS assay that generates reliable outcomes, the present study optimized several factors that may affect the assay results.

Sodium pyruvate-supplemented medium vs. sodium pyruvate-free medium. Sodium pyruvate, a supplement in cell culture medium, may affect the screening assays. As demonstrated in Fig. 1, when the H9c2 cells were maintained in DMEM containing $110 \mathrm{mg} / \mathrm{l}$ sodium pyruvate, $12.5-200 \mu \mathrm{mol} / \mathrm{l}$ $\mathrm{H}_{2} \mathrm{O}_{2}$ induced a decrease in cell viabilities ( $<7 \%$; Fig. $1 \mathrm{~A}$ and $\left.\mathrm{B}\right)$. However, $\mathrm{H}_{2} \mathrm{O}_{2}$ treatment of the cells in sodium pyruvate-free DMEM resulted in a more marked decrease $(\sim 40 \%)$ in cell viability (Fig. 1C and D). Therefore, sodium pyruvate-free DMEM was used during the oxidative damage model.

Concentration and incubation time. Optimization experiments were also performed to determine the optimal working concentration and incubation time of $\mathrm{H}_{2} \mathrm{O}_{2}$. $\mathrm{H} 9 \mathrm{c} 2$ cells were exposed to varying degrees of oxidative stress by treatment with $\mathrm{H}_{2} \mathrm{O}_{2}$ for 0-4 h. The results demonstrated that $\mathrm{H}_{2} \mathrm{O}_{2}$ reduced cell viability in a dose- and time-dependent manner in the pyruvate-free groups, and exhibited an almost $40 \%$ injury at $50 \mu \mathrm{mol} / \mathrm{l}$ for $3 \mathrm{~h}$. Higher concentrations or longer incubation time did not result in a more significant change to the OD450 values (Fig. 1C and D).

Cell density. A low number of cells per well may cause low response values, however, a large cell number is not conducive to cell growth, due to the contact inhibition. Thus, determining the appropriate number of cells is essential for drug screening. As demonstrated in Fig. 2, 1.5-4.0x10 ${ }^{4}$ cells/well treated with $50 \mu \mathrm{mol} / 1 \mathrm{H}_{2} \mathrm{O}_{2}$ for $3 \mathrm{~h}$ exhibited consistent results, whereas

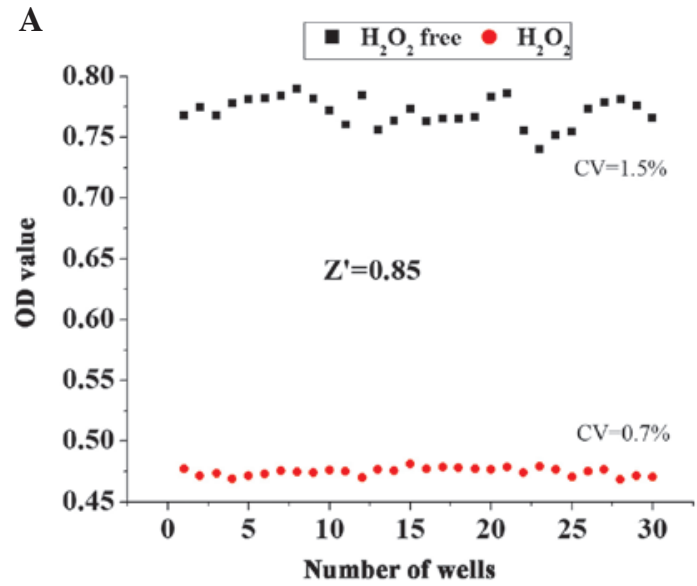

B

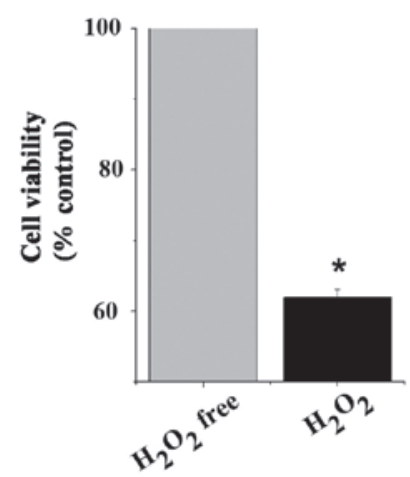

Figure 3. Testing the reproducibility of the oxidative damage model in an automated 96-well assay format. $\mathrm{H} 9 \mathrm{c} 2$ cells $(100 \mu \mathrm{l} /$ well $)$ at $3.0 \times 10^{4}$ cells $/ \mu \mathrm{l}$ were seeded into 96-well plates. $\mathrm{H}_{2} \mathrm{O}_{2}$-free wells ( 30 wells) and $\mathrm{H}_{2} \mathrm{O}_{2}$-treated wells (30 wells) were used as positive and negative controls, respectively. Following treatment with $50 \mu \mathrm{mol} / 1 \mathrm{H}_{2} \mathrm{O}_{2}$ at $37^{\circ} \mathrm{C}$ and $5 \% \mathrm{CO}_{2}$ for $3 \mathrm{~h}$, cell viabilities were assessed using CCK- 8 assay by measuring absorbance at $450 \mathrm{~nm}$. The data are presented as (A) CCK-8 readings from individual wells and (B) as the mean \pm standard deviation of 30 wells. ${ }^{*} \mathrm{P}<0.001$ vs. $\mathrm{H}_{2} \mathrm{O}_{2}$-free wells. OD, optical density; CCK-8, cell counting kit-8.

higher seeding densities exhibited reduced cell viability. Thus, the current study used the cell density of $3.0 \times 10^{4}$ cells/well for the HTS assays.

Variability and robustness of model. To assess whether the model of oxidative damage can be applied to an HTS format, the present study applied the optimized conditions to establish the $\mathrm{H}_{2} \mathrm{O}_{2}$-induced cell damage model. The data of the cell viabilities from 30 wells of positive control $\left(\mathrm{H}_{2} \mathrm{O}_{2}\right.$-free) and 30 wells of negative control $\left(\mathrm{H}_{2} \mathrm{O}_{2}\right.$-treated) were obtained to analyze variability between wells and the robustness of the cell model of oxidative stress using the $\mathrm{Z}$ factor, which is calculated from the following formula: $Z^{\prime}=1-\left[3 \mathrm{x}\left(\delta_{\mathrm{c}}{ }^{+}-\delta_{\mathrm{c}}{ }^{-}\right) /\left(\mu_{\mathrm{c}}{ }^{+}-\mu_{\mathrm{c}}{ }^{-}\right)\right] ; \delta_{\mathrm{c}}{ }^{+}=\mathrm{SD}$ of positive control; $\delta_{\mathrm{c}}{ }^{-}=\mathrm{SD}$ of negative control; $\mu_{\mathrm{c}}{ }^{+}=$mean of positive control; and $\mu_{\mathrm{c}}=$ mean of negative control. $Z^{\prime} \geq 0.5$ indicates the assay method can be performed effectively in HTS (25). As presented in Fig. 3, treatment of $\mathrm{H} 9 \mathrm{c} 2$ cells with $50 \mu \mathrm{mol} / \mathrm{l}$ $\mathrm{H}_{2} \mathrm{O}_{2}$ for $3 \mathrm{~h}$ produced a $\mathrm{Z}^{\prime}$ value of $\sim 0.85$ and small critical values (CVs) $(0.7 \%$ for positive control and $1.5 \%$ for negative control). These results demonstrated that there was an appropriate separation between the SDs of the $\mathrm{H}_{2} \mathrm{O}_{2}$-induced cell damage model and the untreated controls.

The incubation time of the TCM extracts may be an important factor that affects the result of the assay. A positive control 
A

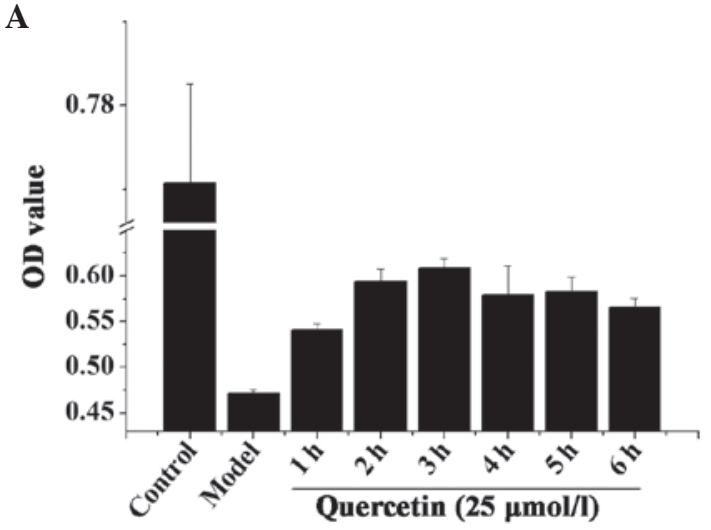

B

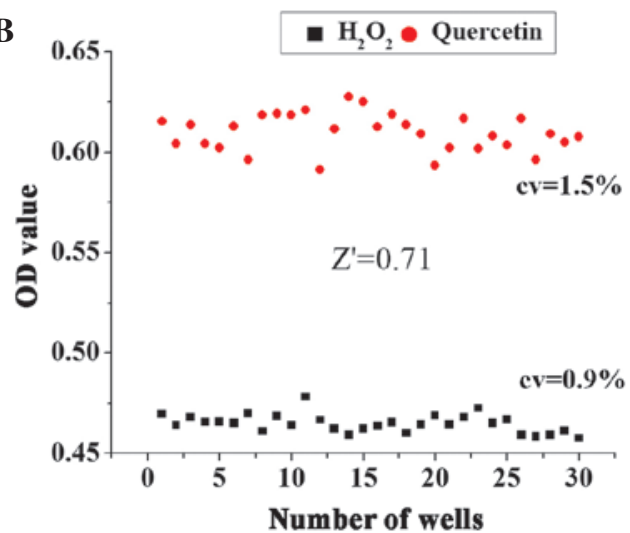

Figure 4. Optimization of the incubation time of $\mathrm{H}_{2} \mathrm{O}_{2}$-treated cells with samples and evaluation of the robustness of the screening method in a high-throughput format. $\mathrm{H} 9 \mathrm{c} 2$ cells $(100 \mu \mathrm{l} /$ well $)$ at a density of $3.0 \times 10^{4}$ cells $/ \mu \mathrm{l}$ were plated into 96-well plates. $\mathrm{H} 9 \mathrm{c} 2$ cells were treated with $50 \mu \mathrm{mol} / 1 \mathrm{H}_{2} \mathrm{O}_{2}$ for $3 \mathrm{~h}$ (model group) or incubated with $25 \mu \mathrm{mol} / 1$ quercetin for a further 1-6 h. Control group was treated with dimethyl sulfoxide only. The cell viabilities were then assessed using cell counting kit- 8 assay, measuring absorbance at $450 \mathrm{~nm}$. (A) The data are presented as the mean \pm standard deviation of 30 wells at the different time points, and (B) as individual wells following the 3-h treatment with $50 \mu \mathrm{mol} / 1 \mathrm{H}_{2} \mathrm{O}_{2}$ and $25 \mu \mathrm{mol} / 1$ quercetin for an additional $3 \mathrm{~h}$. Data from 30 wells of positive controls $\left(\mathrm{H}_{2} \mathrm{O}_{2}+\right.$ quercetin) and 30 wells of negative controls $\left(\mathrm{H}_{2} \mathrm{O}_{2}+\right.$ vehicle) were used for the calculation of $Z^{\prime}$ factor and critical value. OD, optical density.

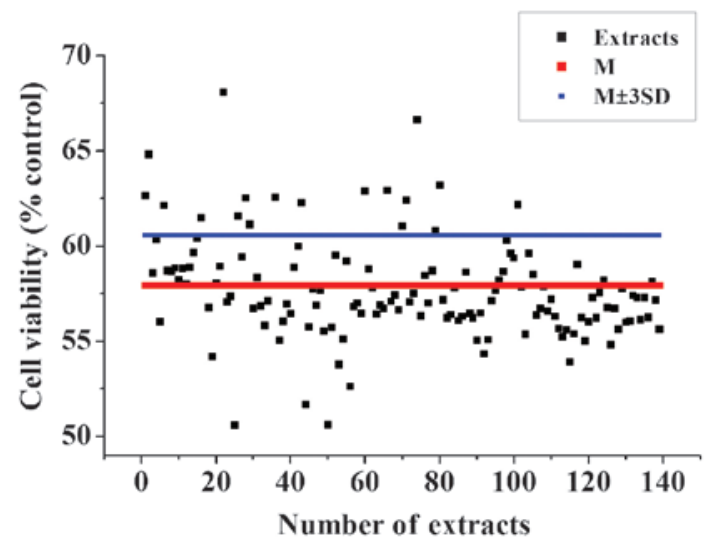

Figure 5. Identification of hits from the traditional Chinese medicine extracts library in HTS assay format. Assays were performed in the optimized automated HTS format. Representative values of the absorbance at $450 \mathrm{~nm}$ of 140 samples are presented. The red line indicates the mean of the negative control, and the blue line indicates the mean of negative control \pm 3 standard deviations. Samples that exhibited $450 \mathrm{~nm}$ absorbance values above the blue line were considered to be hits. HTS, high-throughput screening.

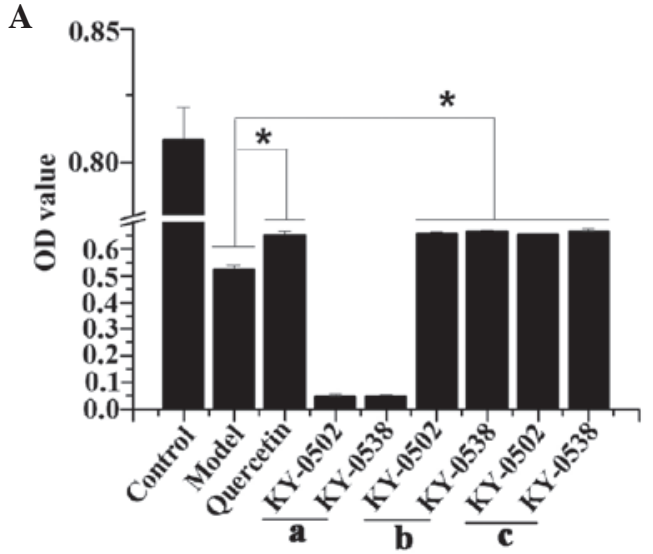

B

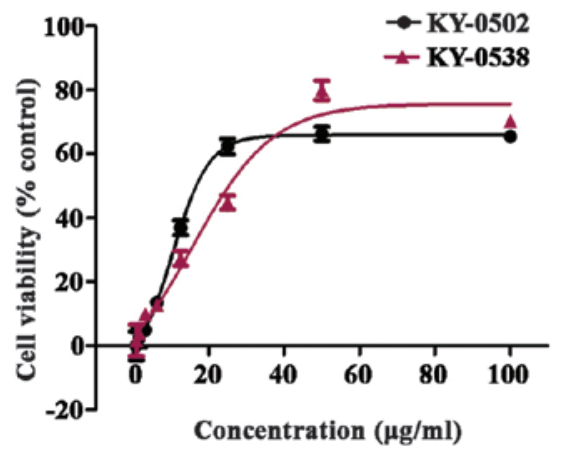

Figure 6. Verification of the activities of the primary hits. The two hits KY-0502 and KY-0538 were further confirmed as candidates in the secondary screening assays. (A) To exclude false positive hits, (a) the primary hit molecules were added to the wells only containing sodium pyruvate-free medium without cells; (b) $\mathrm{H} 9 \mathrm{c} 2$ cells $(100 \mu \mathrm{l} / \mathrm{well})$ at $3.0 \times 10^{4}$ cells $/ \mathrm{ml}$ were plated into 96-well plates, cells were pretreated with $50 \mu \mathrm{mol} / 1 \mathrm{H}_{2} \mathrm{O}_{2}$ for $3 \mathrm{~h}$, then the medium was replaced with sodium pyruvate-free medium containing $25 \mu \mathrm{g} / \mathrm{ml}$ primary hits, and incubated for an additional $3 \mathrm{~h}$; (c) cells were treated with $50 \mu \mathrm{mol} / 1 \mathrm{H}_{2} \mathrm{O}_{2}$ for $3 \mathrm{~h}, 25 \mu \mathrm{g} / \mathrm{ml}$ primary hits were then directly added to wells followed by a 3 -h incubation. ${ }^{*} \mathrm{P}<0.0001 \mathrm{vs}$. model group. (B) The concentration-dependent effects of KY-0502 and KY-0538 on the viability of $\mathrm{H} 9 \mathrm{c} 2$ cells was measured. H9c2 cells (100 $\mu 1 /$ well) at $3.0 \times 10^{4}$ cells $/ \mathrm{ml}$ were plated into 96 -well plates, and treated with $50 \mu \mathrm{mol} / 1$ $\mathrm{H}_{2} \mathrm{O}_{2}$ for $3 \mathrm{~h}$. Subsequently, the cells were incubated with different concentrations of KY-0502 and KY-0538 for an additional $3 \mathrm{~h}$, and cell viabilities were tested at $450 \mathrm{~nm}$. Data are presented as the mean \pm standard deviation of triplicate measurements. OD, optical density.

drug, quercetin, was used to optimize the incubation time of the cells with the drug following oxidative damage. Following $3 \mathrm{~h}$ treatment with $50 \mu \mathrm{mol} / 1 \mathrm{H}_{2} \mathrm{O}_{2}, 25 \mu \mathrm{mol} / \mathrm{l}$ quercetin was added to $\mathrm{H} 9 \mathrm{c} 2$ cells and incubated for an additional 1-6 h. The results demonstrated that the optimal drug incubation time following oxidative damage was $3 \mathrm{~h}$ (Fig. 4A).

The optimized incubation time was used to establish the screening assays, and Z' factor calculation validated whether the assays were suitable for an HTS format. Quercetin-treated cells (pretreated with $50 \mu \mathrm{mol} / 1 \mathrm{H}_{2} \mathrm{O}_{2}$ for $3 \mathrm{~h}$ ) were used as the positive control and the cells treated with $\mathrm{H}_{2} \mathrm{O}_{2}$ only as the negative control to further investigate the robustness of the screening assays in an HTS format. As demonstrated in Fig. 4B, quercetin increased the cell viabilities compared with $50 \mu \mathrm{mol} / 1 \mathrm{H}_{2} \mathrm{O}_{2}$ treatment. The $\mathrm{Z}^{\prime}$ factor was 0.71 , and the CVs of the positive and negative controls were 0.9 and $1.5 \%$, respectively. This indicated that the $\mathrm{H}_{2} \mathrm{O}_{2}$-induced cell damage model was suitable for HTS assays. 
A

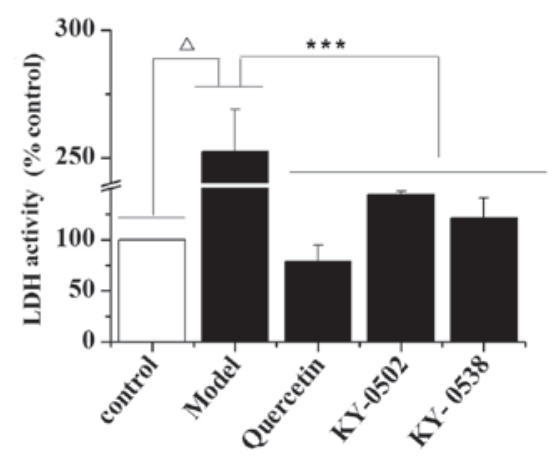

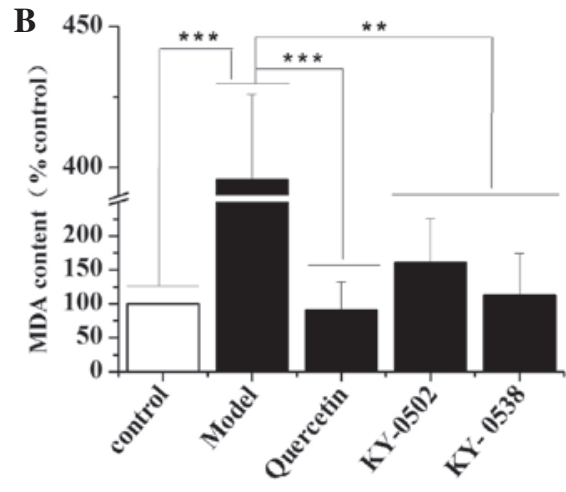

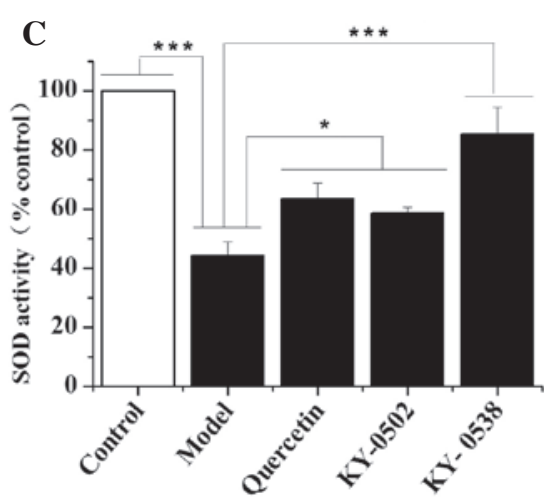

Figure 7. Effects of KY-0502 and KY-0538 on LDH levels, MDA levels and SOD activity in $\mathrm{H}_{2} \mathrm{O}_{2}$-treated $\mathrm{H} 9 \mathrm{c} 2$ cells. H9c2 cells (1,000 $\mu 1 /$ well) at the density of $3.0 \times 10^{4}$ cells $/ \mathrm{ml}$ were seeded into 24 -well plates and randomly divided into five groups. The cells were treated with dimethyl sulfoxide (control group), $50 \mu \mathrm{mol} / 1 \mathrm{H}_{2} \mathrm{O}_{2}$ (model group), $50 \mu \mathrm{mol} / 1 \mathrm{H}_{2} \mathrm{O}_{2}+50 \mu \mathrm{mol} / 1$ quercetin (quercetin group), $25 \mu \mathrm{g} / \mathrm{ml} \mathrm{KY}-0502$ (KY-0502 group) or $25 \mu \mathrm{g} / \mathrm{ml} \mathrm{KY-0538} \mathrm{(KY-0538}$ group). Subsequently, the cells and medium were collected for LDH, MDA and SOD detection using the corresponding assay kits. (A) LDH contents released from the cells, (B) MDA contents of the cells and (C) SOD activities of the cells. ${ }^{*} \mathrm{P}<0.05,{ }^{* *} \mathrm{P}<0.01,{ }^{* * * *} \mathrm{P}<0.001$ and ${ }^{\Delta} \mathrm{P}<0.0001$, comparisons indicated by brackets. LDH, lactate dehydrogenase; MDA, malondialdehyde; SOD, superoxide dismutase.

Identification of active extracts from TCM. The optimized 96-well plate HTS system was then used to identify extracts with antioxidative activity from a TCM library. After a 3-h treatment with $50 \mu \mathrm{mol} / 1 \mathrm{H}_{2} \mathrm{O}_{2}$, and a 3-h incubation with TCM extracts at $37^{\circ} \mathrm{C}$ and $5 \% \mathrm{CO}_{2}$, the cell viabilities were determined using the CCK-8 kit and absorbance measured at $450 \mathrm{~nm}$. In addition to the extracts, $0.1 \mu \mathrm{l} /$ well $25 \mathrm{mg} / \mathrm{ml}$ DMSO solution was added to the cells. The final concentration of the samples in each well was $\sim 25 \mu \mathrm{g} / \mathrm{ml}$. This concentration exhibited low cytotoxic effects on the cells (data not shown). The extracts that exhibited an OD450 value $>$ the mean $\pm 3 \mathrm{SD}$ of the negative control $\left(\mathrm{H}_{2} \mathrm{O}_{2}\right.$-treated $)$ were considered as potential active samples. The top 17 hits from the primary screening were selected for further validation (Fig. 5).

Validation of the primary hits. The increased OD450 values observed in the HTS assay may be due to increased cell viabilities via protection of cells from oxidative damage, reduced $\mathrm{H}_{2} \mathrm{O}_{2}$ toxicity by a direct reaction with $\mathrm{H}_{2} \mathrm{O}_{2}$ in the culture medium, or extract compounds themselves may absorb at $450 \mathrm{~nm}$. In order to exclude false positives, the current study further validated the primary hits. To determine whether the extract samples absorbed at $450 \mathrm{~nm}, 0.1 \mu \mathrm{l}$ primary hit extracts were directly added to the wells of a 96-well plate containing $100 \mu 1$ pyruvate-free DMEM (no cells), and incubated for $3 \mathrm{~h}$. The results demonstrated that two extracts KY-0520 and KY-0538 had no significant absorption at $450 \mathrm{~nm}$ (Fig. 6Aa). In order to test whether $\mathrm{H}_{2} \mathrm{O}_{2}$ directly reacts with the extracts in the culture medium, cells were pretreated with $50 \mu \mathrm{mol} / 1$ $\mathrm{H}_{2} \mathrm{O}_{2}$ for $3 \mathrm{~h}$, then the culture medium was replaced with pyruvate-free DMEM containing $25 \mu \mathrm{g} / \mathrm{ml}$ primary hit and incubated for additional $3 \mathrm{~h}$. The results indicated that KY-0520 and KY-0538 increased cell viability compared with the $\mathrm{H}_{2} \mathrm{O}_{2}$-only treatment when in the culture media with $\mathrm{H}_{2} \mathrm{O}_{2}$, and when $\mathrm{H}_{2} \mathrm{O}_{2} / \mathrm{KY}-0520$ and $\mathrm{KY}-0538$ treatments were performed individually (Fig. 6Ab and c). Taken together, the results indicate that activities of KY-0520 and KY-0538 were due to antioxidative properties. The present study additionally measured the cell viability following treatment with
KY-0520 and KY-0538 at different concentrations. H9c2 cell viability was increased by KY-0520 and KY-0538 in a concentration-dependent manner. The concentration-response curves of KY-0520 and KY-0538 demonstrated that the compounds are active between of 0.78 and $100 \mu \mathrm{g} / \mathrm{ml}$ (Fig. 6B), and the $\mathrm{EC}_{50}$ values of KY-0520 and KY-0538 were 11.43 and $19.59 \mu \mathrm{g} / \mathrm{ml}$, respectively.

Characterization of the cardioprotective activities of KY-0520 and $K Y$-0538. The present study further investigated the antioxidant activity of the TCM extracts. The results demonstrated that $\mathrm{H}_{2} \mathrm{O}_{2}$-induced oxidative damage to $\mathrm{H} 9 \mathrm{c} 2$ cells significantly increased LDH activity $(\mathrm{P}<0.0001$; Fig. 7A) and MDA levels $(\mathrm{P}<0.001$; Fig. 7B), and decreased SOD activity $(\mathrm{P}<0.001$; Fig. 7C) compared with the control. KY-0520 and KY-0538 treatment $(25 \mu \mathrm{g} / \mathrm{ml})$ significantly reduced the LDH activity $(\mathrm{P}<0.001$; Fig. 7A) and MDA levels $(\mathrm{P}<0.01$; Fig. $7 \mathrm{~B})$ compared with $\mathrm{H}_{2} \mathrm{O}_{2}$-treated cells. Additionally, KY-0520 and KY-0538 significantly increased the SOD activity levels compared with $\mathrm{H}_{2} \mathrm{O}_{2}$-treated cells $(\mathrm{P}<0.05$ and $\mathrm{P}<0.001$, respectively; Fig. 7C). These results suggest that KY-0520 and KY-053 prevent the accumulation of free radicals and attenuate cardiomyocyte damage induced by $\mathrm{H}_{2} \mathrm{O}_{2}$.

TCM extracts decrease $\mathrm{H}_{2} \mathrm{O}_{2}$-induced apoptosis in $\mathrm{H} 9 \mathrm{c} 2$ cells. Based on the cell viability and antioxidative results, the current study further examined whether KY-0520 and KY-0538 exhibited protective effects against $\mathrm{H}_{2} \mathrm{O}_{2}$-induced cell apoptosis by western blot analysis of apoptosis-associated proteins (Fig. 8A). As demonstrated in Fig. 8B and C, $\mathrm{H}_{2} \mathrm{O}_{2}$ treatment significantly increased the protein expression levels of cleaved caspase-3 (1.31-fold increase; $\mathrm{P}<0.05$;) and $\mathrm{Bax}$ (3.19-fold increase; $\mathrm{P}<0.01)$ compared with the untreated controls. KY-0520 and KY-0538 (25 $\mu \mathrm{g} / \mathrm{ml})$ significantly decreased the protein expression levels of cleaved caspase-3 $(\mathrm{P}<0.05)$ and $\mathrm{Bax}(\mathrm{P}<0.01)$ in $\mathrm{H} 9 \mathrm{c} 2$ cells compared with $\mathrm{H}_{2} \mathrm{O}_{2}$ treatment alone. Additionally, the protein levels of Bcl-2, an anti-apoptotic protein, were decreased following $\mathrm{H}_{2} \mathrm{O}_{2}$ treatment compared with untreated controls $(\mathrm{P}<0.05)$, however, compared with $\mathrm{H}_{2} \mathrm{O}_{2}$ treatment alone, Bcl-2 levels were 
B
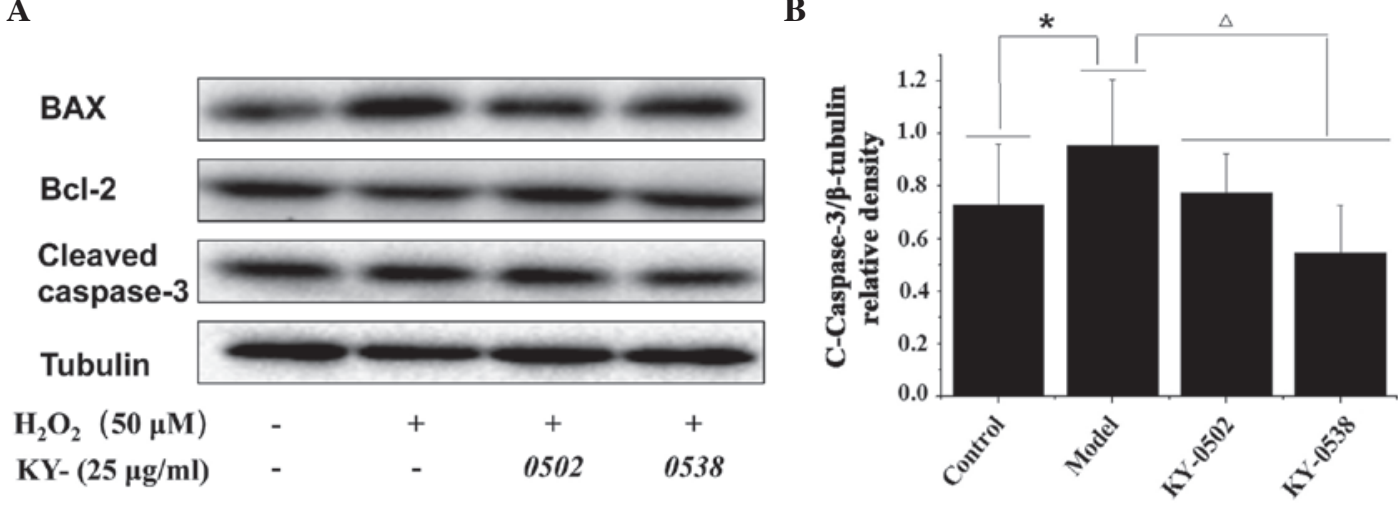

C

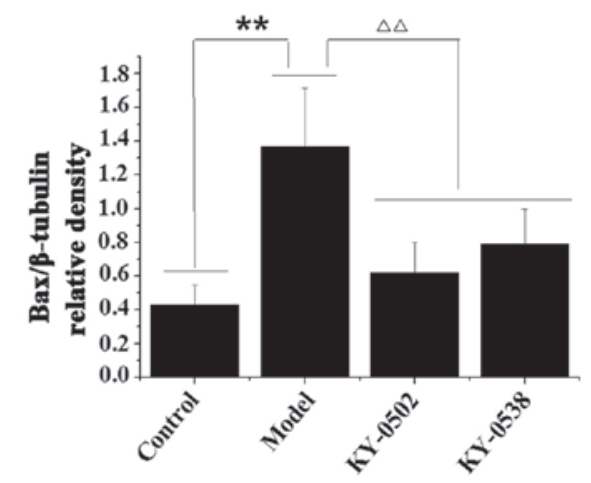

D

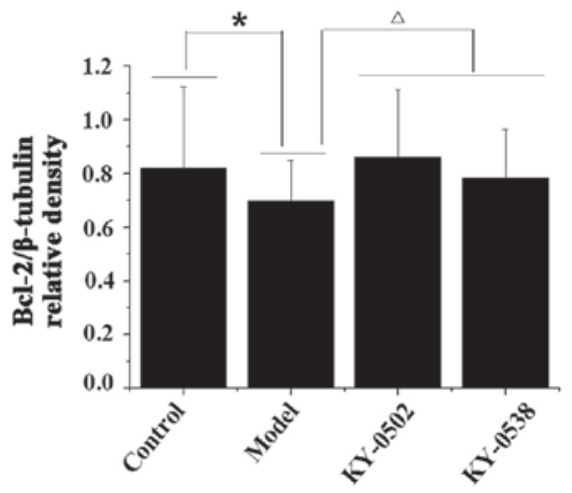

Figure 8. Effect of traditional Chinese medicine extracts on $\mathrm{H}_{2} \mathrm{O}_{2}$-induced apoptosis in $\mathrm{H} 9 \mathrm{c} 2$ cells. Cells were stimulated with $50 \mu$ mol/1 $\mathrm{H}_{2} \mathrm{O}_{2}$ for $3 \mathrm{~h}$ (model group) or treated with $25 \mu \mathrm{g} / \mathrm{ml} \mathrm{KY-0502} \mathrm{and} \mathrm{KY-0538} \mathrm{for} \mathrm{an} \mathrm{additional} 3 \mathrm{~h}$. Control group were treated with DMSO only. After the cells were lysed, total proteins $(50 \mu \mathrm{g})$ were separated on $12 \%$ SDS-PAGE and detected by immunoblotting. (A) Western blot analysis of apoptotic proteins and quantification of (B) Bcl-2, (C) Bax and (D) cleaved caspase-3 protein expression levels, $\beta$-tubulin was used for normalization. Western blot images are representative of three independent experiments and data are presented as the mean \pm standard deviation $(\mathrm{n}=3)$. ${ }^{*} \mathrm{P}<0.05,{ }^{* *} \mathrm{P}<0.01$ vs. control group; ${ }^{\Delta} \mathrm{P}<0.05,{ }^{\Delta \Delta} \mathrm{P}<0.01 \mathrm{vs}$. model group. Bcl-2, B-cell CLL/lymphoma 2; Bax, Bcl-2-associated X protein; C-caspase, cleaved caspase.

significantly increased following KY-0520 and KY-0538 treatment $(\mathrm{P}<0.05$; Fig. 8D). The results indicated that the extracts inhibited apoptosis by regulation of pro- and anti-apoptotic proteins in $\mathrm{H}_{2} \mathrm{O}_{2}$-treated $\mathrm{H} 9 \mathrm{c} 2$ cells.

TCM extracts inhibit Egr-1 protein accumulation in nucleus in $\mathrm{H}_{2} \mathrm{O}_{2}$-exposed $\mathrm{H} 9 \mathrm{c} 2$ cells. It was previously demonstrated that following exposure of $\mathrm{H} 9 \mathrm{c} 2$ cells to $200 \mu \mathrm{mol} / 1 \mathrm{H}_{2} \mathrm{O}_{2}$, Egr-1 is translocated from the cytoplasm and accumulates in the nucleus (26). The present study treated $\mathrm{H} 9 \mathrm{c} 2$ cells with $200 \mu \mathrm{mol} / 1 \mathrm{H}_{2} \mathrm{O}_{2}$ for $2 \mathrm{~h}$, however, Egr-1 did not translocate from the cytoplasm to nucleus, it accumulated in the cytoplasm and nuclear membrane (Fig. 9A). By contrast, at an $\mathrm{H}_{2} \mathrm{O}_{2}$ concentration of $12.5 \mu \mathrm{mol} / 1$, Egr-1 nuclear staining was increased (Fig. 9B). KY-0520 and KY-0538 (25 $\mu \mathrm{g} / \mathrm{ml})$ markedly decreased Egr-1 immunostaining to near basal levels, and caused Egr-1 redistribution in the nucleus and cytoplasm (Fig. 9B). These results suggested that KY-0520 and KY-0538 may protect $\mathrm{H} 9 \mathrm{c} 2$ cells from oxidative damage by regulating Egr-1 activity.

TCM extracts inhibit ERK1/2 and p38-MAPK in $\mathrm{H}_{2} \mathrm{O}_{2}$-exposed $H 9 c 2$ cells. The MAPK signaling pathways, including ERK1/2, p38 and JNK-MAPK, are critical for the regulation of apoptosis and other cellular processes. Activation of the MAPK signaling pathways is a characteristic feature of oxidant-induced apoptosis (27), and is well established in cardiac myocytes (28). In the present study, the protein levels of p-ERK1/2, p-JNK and p-p38 MAPK were measured in $\mathrm{H} 9 \mathrm{c} 2$ cells exposed to $12.5 \mu \mathrm{mol} / 1 \mathrm{H}_{2} \mathrm{O}_{2}$, and the results are presented in Fig. 10. Western blot analysis demonstrated that the phosphorylation levels of p42- and p44-ERK and p38 MAPK were significantly increased by $\mathrm{H}_{2} \mathrm{O}_{2}$ (2.04-, 1.37- and 1.88-fold, respectively) compared with untreated control cells (Fig. 10B and C). However the increased phosphorylation of those kinases was reversed by $25 \mu \mathrm{g} / \mathrm{ml} \mathrm{KY-0520} \mathrm{and} \mathrm{KY-0538}$ after $3 \mathrm{~h}$ incubation. However, no significant alterations in JNK phosphorylation were observed following $12.5 \mu \mathrm{mol} / 1 \mathrm{H}_{2} \mathrm{O}_{2}$ or $25 \mu \mathrm{g} / \mathrm{ml}$ active extracts treatment (Fig. 10D). These results indicate that KY-0520 and KY-0538 may regulate the MAPK signaling pathway to protect against $\mathrm{H}_{2} \mathrm{O}_{2}$-induced oxidative stress in $\mathrm{H} 9 \mathrm{c} 2$ cells.

\section{Discussion}

Increasingly, studies indicate that ROS are associated with the pathogenesis and progression of various cardiovascular diseases. Sensitivity to oxidative stress is greater in the heart compared with other organs due to lower levels of antioxidant enzymes (29). The pathogenesis of cardiac hypertrophy, developed by chronic hypertrophy, is associated with ROS via regulation of the intracellular pathways linked to MAPKs and phosphatidylinositol-4,5-bisphosphate 3-kinase/Akt (30-32). $\mathrm{H}_{2} \mathrm{O}_{2}$ is predominantly produced via the dismutation of 
A
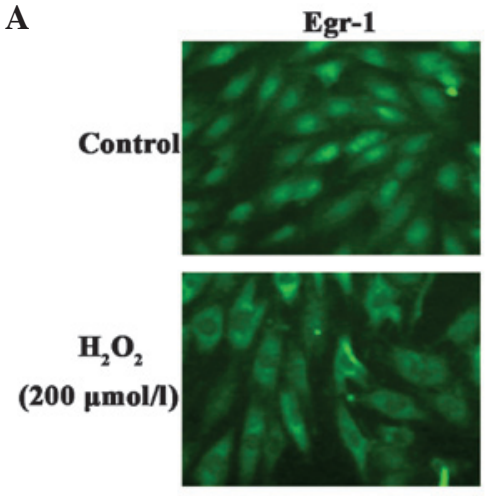

B

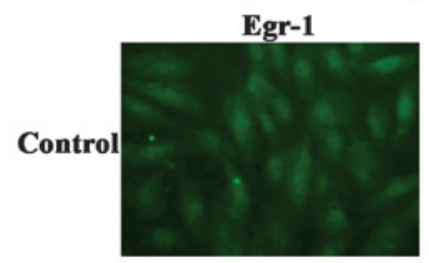

$\mathbf{H}_{2} \mathbf{O}_{2}$

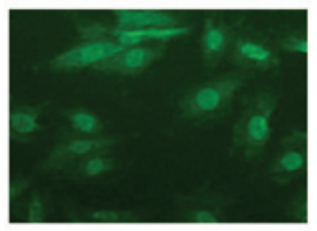

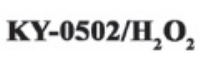
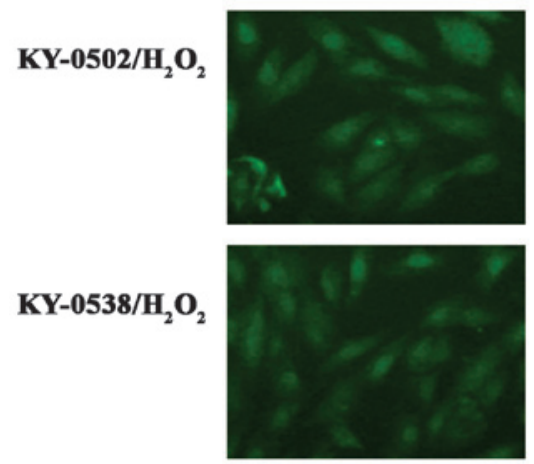
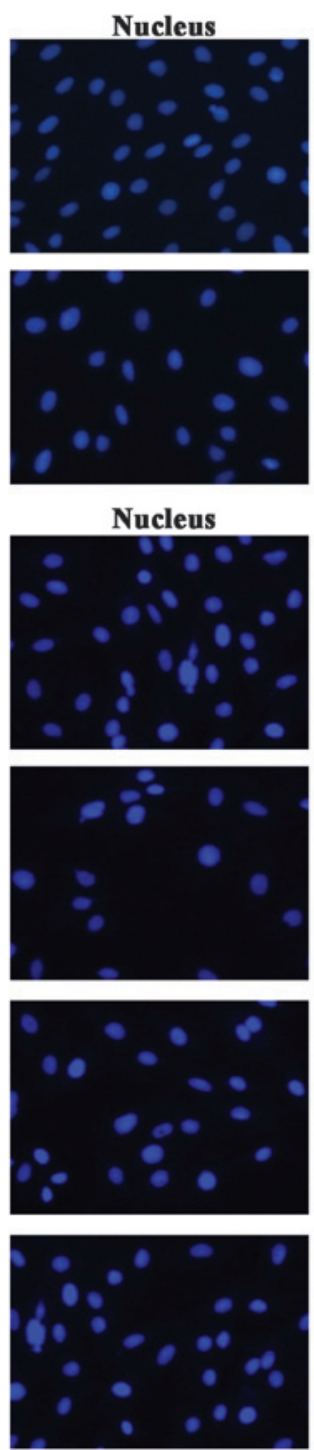
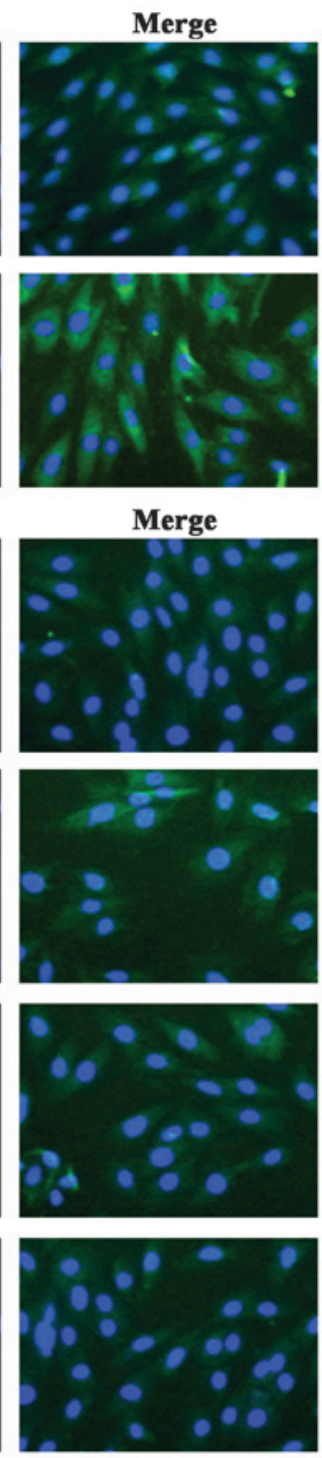

Figure 9. Cellular localization of Egr-1 in $\mathrm{H} 9 \mathrm{c} 2$ cells exposed to different concentrations of $\mathrm{H}_{2} \mathrm{O}_{2}$ and traditional Chinese medicine extracts. Cells were subjected to immunocytochemical analysis with an antibody directed against total Egr-1 (green). To reveal nuclear morphology, the nuclei were stained with Hoechst 33258 (blue). The images were captured using a fluorescence microscope. Representative images are indicative of $\geq 3$ independent experiments. (A) Cells were untreated (control) or incubated with $200 \mu \mathrm{mol} / 1 \mathrm{H}_{2} \mathrm{O}_{2}$ for $2 \mathrm{~h}$. (B) Cells were untreated (control) or incubated with either $12.5 \mu \mathrm{mol} / 1 \mathrm{H} \mathrm{O}_{2}$ or $12.5 \mu \mathrm{mol} / 1 \mathrm{H}_{2} \mathrm{O}_{2}$ followed by treatment with $25 \mu \mathrm{g} / \mathrm{ml} \mathrm{KY-0502} \mathrm{or} \mathrm{KY-0538} \mathrm{for} 2 \mathrm{~h}$. Egr-1, early growth response-1.

superoxide anions, it can also swiftly permeate the cell membrane and react with intracellular metal ions to form toxic hydroxyl radicals, which cause DNA damage (33). Previous studies demonstrated that $\mathrm{H}_{2} \mathrm{O}_{2}$ is excessively produced during cardiomyocyte apoptosis, leading to caspase-3 activation via mitochondrial dysfunction and cytosolic release of mitochondrial cytochrome $c$ (34).

Numerous studies have investigated natural plant compounds and TCM extracts for their antioxidant activities. Silibinin (the major active component of silymarin extracted from $S$. marianum) has been demonstrated to have antioxidative, antitumor and anti-inflammatory properties (35). The volatile oil of Nardostachyos Radix et Rhizoma (the root and rhizome of Nardostachys jatamansi DC.) was reported to markedly suppress ROS formation and dose-dependently increase glutathione levels in $\mathrm{H} 9 \mathrm{c} 2$ cells following oxidative injury (36). Thus, novel antioxidant agents from natural plants and TCM may be useful for the treatment of cardiac diseases.
Using $\mathrm{H}_{2} \mathrm{O}_{2}$ to treat $\mathrm{H} 9 \mathrm{c} 2$ rat myocardial cells, the present study established a cell model of oxidative damage for HTS assay, and used the model to identify cardioprotective agents from a library of TCM extracts. The actions of the extract were determined by CCK-8 assay, which is based on dehydrogenase activity detection in viable cells, and is widely used for cell proliferation and cytotoxicity assays. The CCK- 8 assay does not require washing or cell lysis, therefore, variability is minimized. It has previously been successfully applied in HTS studies as it is inexpensive and easy to operate (37). Therefore, the present study used the CCK-8 assay to evaluate the effect of TCM extracts on the viability of oxidatively damaged cells. Two hits, KY-0520 and KY-0538, were further validated as cardioprotective agents, and attenuated oxidative damage in a concentration-dependent manner $\left(\mathrm{EC}_{50}\right.$ values, $\sim 11.43$ and $19.59 \mu \mathrm{g} / \mathrm{ml}$, respectively).

The present study used $50 \mu \mathrm{mol} / 1 \mathrm{H}_{2} \mathrm{O}_{2}$ to induce oxidative damage in the model. Various studies have investigated 
A
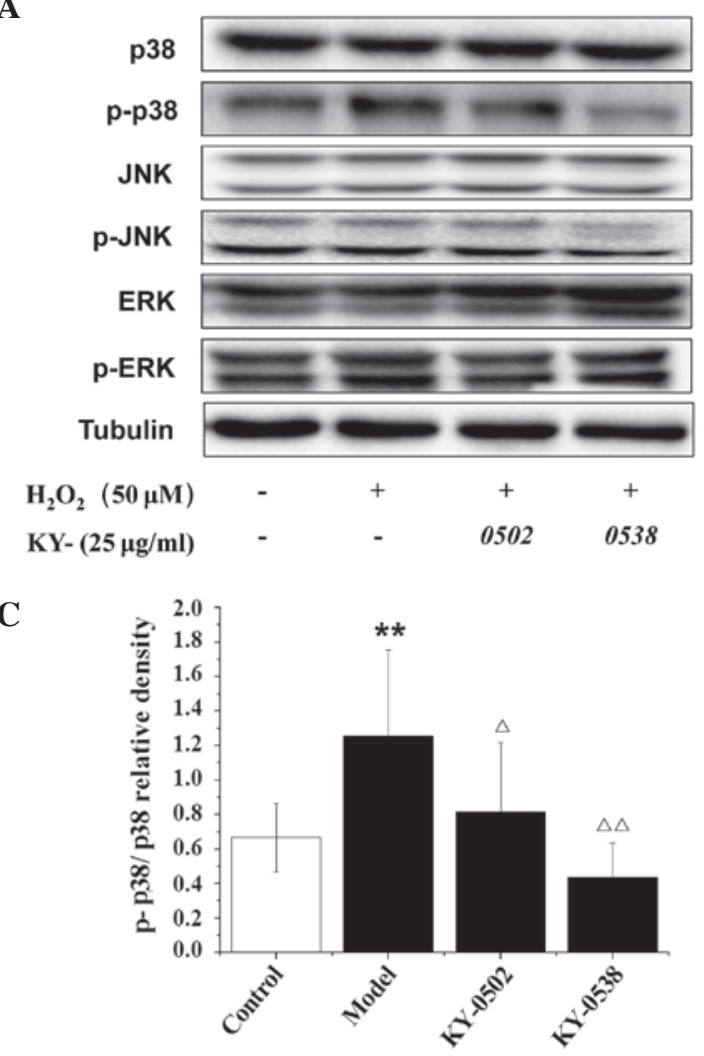

B

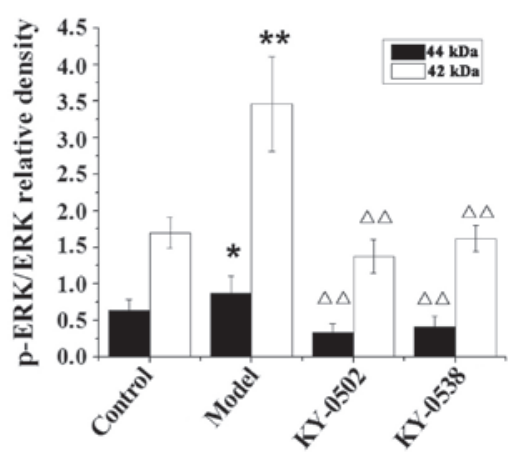

D

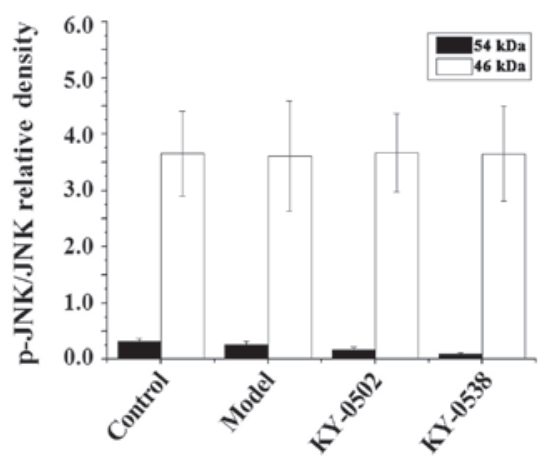

Figure 10. Effects of traditional Chinese medicine extracts on ERK1/2, p38 and JNK phosphorylation in $\mathrm{H}_{2} \mathrm{O}_{2}$-treated H9c2 cells. Cells were stimulated with $12.5 \mathrm{~mol} / 1 \mathrm{H}_{2} \mathrm{O}_{2}$ for $3 \mathrm{~h}$ (model group) or treated with $25 \mu \mathrm{g} / \mathrm{ml} \mathrm{KY-0502/KY-0538} \mathrm{for} \mathrm{an} \mathrm{additional} 3 \mathrm{~h}$. Control cells were treated with dimethyl sulfoxide only. The cells were lysed, total proteins $(50 \mu \mathrm{g})$ were separated on $12 \%$ SDS-PAGE and detected by immunoblotting. (A) Western blot analysis and densitometry measuring (B) ERK1/2, (C) P38 MAPK and (D) JNK phosphorylation levels. $\beta$-Tubulin was used for normalization. Western blot images are representative of three independent experiments. Data are presented as the mean \pm standard deviation $(\mathrm{n}=3) .{ }^{*} \mathrm{P}<0.05$ and ${ }^{* *} \mathrm{P}<0.01$ vs. control group; ${ }^{\Delta} \mathrm{P}<0.05$ and ${ }^{\Delta \Delta} \mathrm{P}<0.01$ vs. model group. ERK, mitogen-activated protein kinase 3; p, phospho; P38, mitogen-activated protein kinase 14; JNK, mitogen-activated protein kinase 8.

the appropriate working concentration of $\mathrm{H}_{2} \mathrm{O}_{2}$, however, results have varied $(21,38,39)$. Sodium pyruvate is commonly supplemented in culture media, however, this compound can nonenzymatically react with $\mathrm{H}_{2} \mathrm{O}_{2}$, leading to liberation of $\mathrm{CO}_{2}$, and the conversion of $\alpha$-keto acid to carboxylic acid $(40,41)$. Therefore, the present study used $\mathrm{H}_{2} \mathrm{O}_{2}$ diluted with pyruvate-free DMEM to induce oxidative damage in our cell-based assays.

To establish the HTS assay model, two Z' factors were required to evaluate the screening method. One was used to evaluate the robustness of the cell model, which indicates whether the cell damage model was successfully established and suitable for HTS. The other Z' factor was used to evaluate the robustness of the extract screening assay (Figs. 3 and 4). The majority of HTS assays are based on specific targets. Compared with the HTS assays designed to screen for drugs acting on specific targets, the cell damage model has advantages and limitations. Cell-based screening can directly evaluate the protective activities of drugs by measuring cell viability, however, the direct targets of the drugs and the signaling pathways involved are unclear. To understand the mechanisms of action of the drugs, it is necessary to further investigate the potential targets and signaling pathways. The effects of the drug candidates identified in the present study may be mediated by interaction with multiple targets and signaling pathways. Therefore, the cell-protective functions of KY-0520 and KY-0538 may be mediated by their antioxidant activity, and also via interaction with other pathways. Other factors and pathways associated with the effects of KY-0520 and KY-0538 may include Egr-1. Immunofluorescence demonstrated the localization of Egr-1 to be altered by KY-0520 and KY-0538 treatment under $\mathrm{H}_{2} \mathrm{O}_{2}$-induced oxidative stress.

$\mathrm{H}_{2} \mathrm{O}_{2}$ is a strong oxidant that markedly decreases cell viability and increases apoptosis. The present study measured LDH activity to further investigate the cardioprotective effect of KY-0520 and KY-0538. LDH assays are widely used to quantify the level of LDH release. MDA levels and SOD activity were also measured as indicators of oxidative damage and myocardial function. KY-0520 and KY-0538 demonstrated significant antioxidant activities and protective effects on cardiomyocytes in vitro (Fig. 7). Furthermore, previous studies have demonstrated that $\mathrm{H}_{2} \mathrm{O}_{2}$ can decrease the $\mathrm{Bcl}-2 / \mathrm{Bax}$ ratio and increase the level of cleaved caspase-3, therefore inducing apoptosis $(42,43)$. Western blot analysis demonstrated that KY-0520 and KY-0538 regulate the $\mathrm{Bcl}-2 / \mathrm{Bax}$ ratio in $\mathrm{H}_{2} \mathrm{O}_{2}$-exposed $\mathrm{H} 9 \mathrm{c} 2$ cells, and decrease the $\mathrm{H}_{2} \mathrm{O}_{2}$-induced cleaved caspase-3 activation (Fig. 8). These effects may contribute to the antioxidant activity of KY-0520 and KY-0538 and their protection against oxidative stress.

Egr-1 is a transcription factor encoded by an immediate early gene (44). Egr-1 is weakly expressed under normal conditions, and its expression is activated by various environmental stimuli associated with injury and stress, including growth factors, cytokines, $T$ cell receptor ligation, hormones, thrombin, 
shear stress and mechanical forces, neurotransmitters, ultraviolet light, ROS, ischemia/reperfusion and hypoxia (45-52). Egr-1 mRNA is expressed following cardioplegic arrest and reperfusion in human hearts, and in rat hearts subjected to cold cardioplegia for $40 \mathrm{~min}$ followed by $40 \mathrm{~min}$ reperfusion. The expression of Egr-1 and the downstream effects on transcription are tightly controlled, and cell-specific upregulation induced by processes such as hypoxia and ischemia, has been previously linked to multiple aspects of cardiovascular injury. Egr-1 regulates cell growth and proliferation $(53,54)$, and positively modulates inflammation, thrombosis and apoptosis, by direct and indirect mechanisms $(45,55)$. It was previously reported that targeting rodent Egr-1 selectively reduced the infarct size following myocardial ischemia/reperfusion. The mechanisms reported to be involved were associated with the attenuation of intercellular adhesion molecule 1-dependent inflammation and inhibition of other Egr-1-dependent molecules, including tumor necrosis factor- $\alpha$ (TNF- $\alpha)$, vascular cell adhesion molecule-1 (VCAM-1), tissue factor (TF), plasminogen activator inhibitor type 1, and p53. Inhibition of functional TF, VCAM-1 and TNF- $\alpha$ has been previously demonstrated to reduce the infarct size in experimental models of myocardial ischemia/reperfusion. The transcription of the pro-apoptotic factor, p53, is inhibited by Egr-1, with an associated reduction in apoptosis and infarct size (56). A previous study demonstrated that Egr-1 represses transcription from the calsequestrin (CSQ) promoter, resulting in reduced expression of CSQ, which is a major calcium storage protein critical for normal cardiac function (57). Additionally, overexpression of Egr-1 directly induced caspase activation and apoptosis in human cardiac fibroblast cultures in vitro (58). These studies indicate that inhibition of Egr-1 activity may be cardioprotective.

The findings of the present study were consistent with a previous study that demonstrated that $\mathrm{H}_{2} \mathrm{O}_{2}$ induces the translocation of Egr-1 from the cytoplasm to nucleus, thus promoting the accumulation of Egr-1 in the nuclei of H9c2 cells (Fig. 9B) (26). However, in contrast to the previous study, a high concentration of $\mathrm{H}_{2} \mathrm{O}_{2}(200 \mu \mathrm{mol} / \mathrm{l})$ resulted in high levels of Egr-1 in the cytoplasm and nuclear membrane, rather than accumulation in the nucleus (Fig. 9) (26). The different regulatory mechanisms of Egr-1 under different concentrations of $\mathrm{H}_{2} \mathrm{O}_{2}$ are not clear. KY-0520 and KY-0538 effectively reversed the translocation of Egr-1 from the cytoplasm to the nucleus induced by $12.5 \mu \mathrm{mol} / 1 \mathrm{H}_{2} \mathrm{O}_{2}$ (Fig. 9). The cardioprotective activities of KY-0520 and KY-0538 appear to be associated with inhibition of Egr-1 activity and ROS scavenging.

Egr-1 expression is upregulated in response to cardiac ischemia/reperfusion stress (59). Additionally, a previous study demonstrated that Egr-1 mRNA expression in $\mathrm{H} 9 \mathrm{c} 2$ cells was upregulated by $\mathrm{H}_{2} \mathrm{O}_{2}$ in vitro, and that the upregulation was dependent on MEK/ERK and JNK signaling $(26,60)$. ERK1/2 is a component of the classical MAPK pathway that was previously demonstrated to be directly activated by high levels of ROS (including xanthine oxidase-derived $\mathrm{H}_{2} \mathrm{O}_{2}$ ) leading to transcription of Egr-1 (60-62). Thus, the present study investigated whether these pathways are modified during $\mathrm{H}_{2} \mathrm{O}_{2}$-induced oxidative stress. Consistent with previous studies $(26,63)$, the western blot analysis of the present study indicated that the phosphorylation levels of
ERK1/2 and p38-MAPK kinase were increased following $12.5 \mu \mathrm{mol} / 1 \mathrm{H}_{2} \mathrm{O}_{2}$ treatment (Fig. 10). Therefore, it is speculated that ERK1/2 and p38-MAPK may be important upstream regulators that mediated Egr-1 modulation during cardiomyocyte oxidative stress. The results of the present study indicated that the antioxidative effects of KY-0520 and KY-0538 may be mediated by suppression of the ERK1/2, p38-MAPK/Egr-1 signaling pathways in $\mathrm{H}_{2} \mathrm{O}_{2}$-induced oxidative stress.

In summary, the hits from the HTS assays may generate novel drugs that have the potential to be used as therapeutics for cardiomyocyte diseases, including heart ischemia/reperfusion, cardiac hypertrophy, cardiac dysfunction and heart failure. The present study established and validated $\mathrm{a}_{2} \mathrm{O}_{2}$-induced cell damage model for use in HTS, however, further mechanistic research is required to understand the effects of the identified hits. Further investigation of the activity of the hits will be performed using primary cardiomyocyte cells or appropriate animal models.

\section{Acknowledgements}

The authors of the present study thank the Natural Products Research Department, State Key Laboratory of New-tech for the Chinese Medicine Pharmaceutical Process for providing the TCM extracts library. The current work was supported by the Ministry of Science and Technology of China (no. 2013zx0942203).

\section{References}

1. Galli F, Piroddi M, Annetti C, Aisa C, Floridi E and Floridi A: Oxidative stress and reactive oxygen species. Contrib Nephrol 149: 240-260, 2005.

2. Pham-Huy LA, He H and Pham-Huy C: Free radicals, antioxidants in disease and health. International journal of biomedical science: Int J Biomed Sc 4: 89-96, 2008.

3. Geronikaki AA and Gavalas AM: Antioxidants and inflammatory disease: Synthetic and natural antioxidants with anti-inflammatory activity. Comb Chem High Throughput Screen 9: 425-442, 2006.

4. Guo RF and Ward PA: Role of oxidants in lung injury during sepsis. Antioxid Redox Signal 9: 1991-2002, 2007.

5. Gilgun-Sherki Y, Melamed E and Offen D: Oxidative stress induced-neurodegenerative diseases: The need for antioxidants that penetrate the blood brain barrier. Neuropharmacology 40: 959-975, 2001.

6. Kumar SV, Saritha G and Fareedullah M: Role of antioxidants and oxidative stress in cardiovascular diseases. Ann Biol Res 3: 158-175, 2010.

7. Venardos KM, Perkins A, Headrick J and Kaye DM: Myocardial ischemia-reperfusion injury, antioxidant enzyme systems, and selenium: A review. Cur Med Chem 14: 1539-1549, 2007.

8. Zhao ZQ: Oxidative stress-elicited myocardial apoptosis during reperfusion. Curr Opin Pharmacol 4: 159-165, 2004.

9. Saini HK, Machackova J and Dhalla NS: Role of reactive oxygen species in ischemic preconditioning of subcellular organelles in the heart. Antioxid Redox Signal 6: 393-404, 2004.

10. Zima AV and Blatter LA: Redox regulation of cardiac calcium channels and transporters. Cardiovasc Res 71: 310-321, 2006.

11. Cesselli D, Jakoniuk I, Barlucchi L, Beltrami AP, Hintze TH, Nadal-Ginard B, Kajstura J, Leri A and Anversa P: Oxidative stress-mediated cardiac cell death is a major determinant of ventricular dysfunction and failure in dog dilated cardiomyopathy. Circ Res 89: 279-286, 2001.

12. Kwon SH, Pimentel DR, Remondino A, Sawyer DB and Colucci WS: $\mathrm{H}_{2} \mathrm{O}_{2}$ regulates cardiac myocyte phenotype via concentration-dependent activation of distinct kinase pathways. J Mol Cell Cardiol 35: 615-621, 2003. 
13. Rayment NB, Haven AJ, Madden B, Murday A, Trickey R, Shipley M, Davies MJ and Katz DR: Myocyte loss in chronic heart failure. J Pathol 188: 213-219, 1999.

14. Giordano FJ: Oxygen, oxidative stress, hypoxia, and heart failure J Clin Invest 115: 500-508, 2005.

15. Kimes BW and Brandt BL: Properties of a clonal muscle cell line from rat heart. Exp Cell Res 98: 367-381, 1976.

16. Su CY, Chong KY, Edelstein K, Lille S, Khardori R and Lai CC: Constitutive hsp70 attenuates hydrogen peroxide-induced membrane lipid peroxidation. Biochem Biophys Res Commun 265: 279-284, 1999.

17. Park ES, Kang JC, Kang DH, Jang YC, Yi KY, Chung HJ, Park JS, Kim B, Feng ZP and Shin HS: 5-AIQ inhibits $\mathrm{H}_{2} \mathrm{O}_{2}$-induced apoptosis through reactive oxygen species scavenging and Akt/GSK-3 $\beta$ signaling pathway in $\mathrm{H} 9 \mathrm{c} 2$ cardiomyocytes. Toxicol Appl Pharmacol 268: 90-98, 2013.

18. Aggeli IK, Gaitanaki C and Beis I: Involvement of JNKs and p38-MAPK/MSK1 pathways in $\mathrm{H}_{2} \mathrm{O}_{2}$-induced upregulation of heme oxygenase-1 mRNA in $\mathrm{H} 9 \mathrm{c} 2$ cells. Cell Signal 18 : $1801-1812,2006$

19. Tanaka H, Sakurai K, Takahashi K and Fujimoto Y: Requirement of intracellular free thiols for hydrogen peroxide-induced hypertrophy in cardiomyocytes. J Cell Biochem 89: 944-955, 2003.

20. Qu S, Zhu H, Wei X, Zhang C, Jiang L, Liu Y, Luo Q and Xiao X Oxidative stress-mediated up-regulation of myocardial ischemic preconditioning up-regulated protein 1 gene expression in $\mathrm{H} 9 \mathrm{c} 2$ cardiomyocytes is regulated by cyclic AMP-response element binding protein. Radic Biol Med 49: 580-586, 2010.

21. Law CH, Li JM, Chou HC, Chen YH and Chan HL: Hyaluronic acid-dependent protection in $\mathrm{H} 9 \mathrm{C} 2$ cardiomyocytes: A cell model of heart ischemia-reperfusion injury and treatment. Toxicology 303: 54-71, 2013.

22. Diestel A, Drescher C, Miera O, Berger F and Schmitt KR: Hypothermia protects $\mathrm{H} 9 \mathrm{c} 2$ cardiomyocytes from $\mathrm{H}_{2} \mathrm{O}_{2}$ induced apoptosis. Cryobiology 62: 53-61, 2011.

23. Eguchi M, Liu Y, Shin EJ and Sweeney G: Leptin protects H9c2 rat cardiomyocytes from $\mathrm{H}_{2} \mathrm{O}_{2}$-induced apoptosis. FEBS J 275 3136-3144, 2008.

24. Park ES, Kang JC, Jang YC, Park JS, Jang SY, Kim DE, Kim B and Shin HS: Cardioprotective effects of rhamnetin in $\mathrm{H} 9 \mathrm{c} 2$ cardiomyoblast cells under $\mathrm{H}_{2} \mathrm{O}_{2}$-induced apoptosis. J Ethnopharmacol 153: 552-560, 2014.

25. Zhang JH, Chung TD and Oldenburg KR: A simple statistical parameter for use in evaluation and validation of high throughput screening assays. J Biomol Screen 4: 67-73, 1999.

26. Aggeli IK, Beis I and Gaitanaki C: ERKs and JNKs mediate hydrogen peroxide-induced Egr-1 expression and nuclear accumulation in H9c2 cells. Physiol Res 59: 443-454, 2010.

27. Ryter SW, Kim HP, Hoetzel A, Park JW, Nakahira K, Wang X and Choi AM: Mechanisms of cell death in oxidative stress Antioxid Redox Signal 9: 49-89, 2007.

28. Clerk A, Michael A and Sugden PH: Stimulation of multiple mitogen-activated protein kinase sub-families by oxidative stress and phosphorylation of the small heat shock protein, HSP25/27, in neonatal ventricular myocytes. Biochem J 333: $581-589,1998$.

29. Di Meo S, Venditti P and De Leo T: Tissue protection against oxidative stress. Experientia 52: 786-794, 1996.

30. Bogoyevitch MA: Signalling via stress-activated mitogen-activated protein kinases in the cardiovascular system. Cardiovasc Res 45: 826-842, 2000.

31. Ravingerová T,Barancík M and Strnisková M: Mitogen-activated protein kinases: A new therapeutic target in cardiac pathology. Mol Cell Biochem 247: 127-138, 2003.

32. Wang Y: Mitogen-activated protein kinases in heart development and diseases. Circulation 116: 1413-1423, 2007.

33. Gao Z, Huang K and Xu H: Protective effects of flavonoids in the roots of Scutellaria baicalensis Georgi against hydrogen peroxide-induced oxidative stress in HS-SY5Y cells. Pharmacol Res 43: 173-178, 2001

34. Park C, So HS, Shin CH, Baek SH, Moon BS, Shin SH, Lee HS, Lee DW and Park R: Quercetin protects the hydrogen peroxide-induced apoptosis via inhibition of mitochondrial dysfunction in $\mathrm{H} 9 \mathrm{c} 2$ cardiomyoblast cells. Biochem Pharmacol 66: 1287-1295, 2003

35. Anestopoulos I, Kavo A, Tentes I, Kortsaris A, Panayiotidis M, Lazou A and Pappa A: Silibinin protects H9c2 cardiac cells from oxidative stress and inhibits phenylephrine-induced hypertrophy: Potential mechanisms. J Nutr Biochem 24: 586-594, 2013
36. Maiwulanjiang M, Chen J, Xin G, Gong AG, Miernisha A, Du CY, Lau KM, Lee PS, Chen J, Dong TT, et al: The volatile oil of Nardostachyos Radix et Rhizoma inhibits the oxidative stress-induced cell injury via reactive oxygen species scavenging and Akt activation in H9c2 cardiomyocyte. J Ethnopharmacol 153: 491-498, 2014.

37. Chen B, Mao R, Wang H and She JX: Cell line and drug-dependent effect of ERBB3 on cancer cell proliferation, chemosensitivity, and multidrug actions. Int J High Throughput Screen 1: 49-55, 2010.

38. Li H, Deng Z, Liu R, Loewen S and Tsao R: Carotenoid compositions of coloured tomato cultivars and contribution to antioxidant activities and protection against $\mathrm{H}_{2} \mathrm{O}_{2}$-induced cell death in H9c2. Food Chem 136: 878-888, 2013.

39. Woo SM, Min KJ, Kim S, Park JW, Kim DE, Chun KS, Kim YH, Lee TJ, Kim SH, Choi YH, et al: Silibinin induces apoptosis of HT29 colon carcinoma cells through early growth response-1 (EGR-1)-mediated non-steroidal anti-inflammatory drug-activated gene-1 (NAG-1) up-regulation. Chem Biol Interact 211: 36-43, 2014.

40. O'Donnell-Tormey J, Nathan CF, Lanks K, DeBoer CJ and de la Harpe J: Secretion of pyruvate. An antioxidant defense of mammalian cells. J Exp Med 165: 500-514, 1987.

41. Holleman AF: Notice sur l'action de l'eau oxygénée sur les acides $\alpha$-cétoniques et sur les dicétones 1.2. Recl Trav Chim Pays-Bas Belg 23: 169-172, 1904 (In French).

42. Dorn GW II: Apoptotic and non-apoptotic programmed cardiomyocyte death in ventricular remodelling. Cardiovasc Res 81: 465-473, 2009.

43. Shih PH, Yeh CT and Yen GC: Anthocyanins induce the activation of phase II enzymes through the antioxidant response element pathway against oxidative stress-induced apoptosis. J Agric Food Chem 55: 9427-9435, 2007.

44. Sukhatme VP, Cao XM, Chang LC, Tsai-Morris CH, Stamenkovich D, Ferreira PC, Cohen DR, Edwards SA, Shows TB, Curran T, et al: A zinc finger-encoding gene coregulated with c-fos during growth and differentiation, and after cellular depolarization. Cell 53: 37-43, 1988.

45. Yan SF, Fujita T, Lu J, Okada K, Shan Zou Y, Mackman N, Pinsky DJ and Stern DM: Egr-1, a master switch coordinating upregulation of divergent gene families underlying ischemic stress. Nat Med 6: 1355-1361, 2000.

46. Gaggioli C, Deckert M, Robert G, Abbe P, Batoz M, Ehrengruber MU, Ortonne JP, Ballotti R and Tartare-Deckert S: HGF induces fibronectin matrix synthesis in melanoma cells through MAP kinase-dependent signaling pathway and induction of Egr-1. Oncogene 24: 1423-1433, 2005.

47. Guha M, O'Connell MA, Pawlinski R, Hollis A, McGovern P, Yan SF, Stern D and Mackman N: Lipopolysaccharide activation of the MEK-ERK1/2 pathway in human monocytic cells mediates tissue factor and tumor necrosis factor alpha expression by inducing Elk-1 phosphorylation and Egr-1 expression. Blood 98: 1429-1439, 2001.

48. Hjoberg J, Le L, Imrich A, Subramaniam V, Mathew SI, Vallone J, Haley KJ, Green FH, Shore SA and Silverman ES: Induction of early growth-response factor 1 by platelet-derived growth factor in human airway smooth muscle. Am J Physiol Lung Cell Mol Physiol 286: L817-L825, 2004.

49. Li CJ, Ning W, Matthay MA, Feghali-Bostwick CA and Choi AM: MAPK pathway mediates EGR-1-HSP70-dependent cigarette smoke-induced chemokine production. Am J Physiol Lung Cell Mol Physiol 292: L1297-L1303, 2007.

50. Kaufmann K and Thiel G: Epidermal growth factor and thrombin induced proliferation of immortalized human keratinocytes is coupled to the synthesis of Egr-1, a zinc finger transcriptional regulator. J Cell Biochem 85: 381-391, 2002.

51. Rössler OG and Thiel G: Thrombin induces Egr-1 expression in fibroblasts involving elevation of the intracellular $\mathrm{Ca}^{2+}$ concentration, phosphorylation of ERK and activation of ternary complex factor. Mol Biol 10: 40, 2009.

52. Lohoff M, Giaisi M, Köhler R, Casper B, Krammer PH and Li-Weber M: Early growth response protein-1 (Egr-1) is preferentially expressed in T helper type 2 ( Th2) cells and is involved in acute transcription of the Th2 cytokine interleukin-4. J Biol Chem 285: 1643-1652, 2010.

53. Gashler A and Sukhatme VP: Early growth response protein 1 (Egr-1): Prototype of a zinc-finger family of transcription factors. Prog Nucleic Acid Res Mol Biol 50: 191-224, 1995.

54. Liu C, Rangnekar VM, Adamson E and Mercola D: Suppression of growth and transformation and induction of apoptosis by EGR-1. Cancer Gene Ther 5: 3-28, 1998. 
55. Thiel G and Cibelli G: Regulation of life and death by the zinc finger transcription factor Egr-1. J Cell Physiol 193: 287-292, 2002.

56. Bhindi R, Fahmy RG, McMahon AC, Khachigian LM and Lowe $\mathrm{HC}$ : Intracoronary delivery of DNAzymes targeting human EGR-1 reduces infarct size following myocardial ischaemia reperfusion. J Pathol 227: 157-164, 2012.

57. Kasneci A, Kemeny-Suss NM, Komarova SV and Chalifour LE: Egr-1 negatively regulates calsequestrin expression and calcium dynamics in ventricular cells. Cardiovasc Res 1: 695-702, 2009.

58. Zins K, Pomyje J, Hofer E, Abraham D, Lucas $\mathrm{T}$ and Aharinejad S: Egr-1 upregulates Siva-1 expression and induces cardiac fibroblast apoptosis. Int J Mol Sci 15: 1538-1553, 2014.

59. Aebert H, Cornelius T, Ehr T, Holmer SR, Birnbaum DE, Riegger GA and Schunkert H: Expression of immediate early genes after cardioplegic arrest and reperfusion. Ann Thorac Surg 63: 1669-1675, 1997 .
60. Chen CA, Chen TS and Chen HC: Extracellular signal-regulated kinase plays a proapoptotic role in podocytes after reactive oxygen species treatment and inhibition of integrin-extracellular matrix interaction. Exp Biol Med (Maywood) 237: 777-783, 2012.

61. Hartney T, Birari R, Venkataraman S, Villegas L, Martinez M, Black SM, Stenmark KR and Nozik-Grayck E: Xanthine oxidase-derived ROS upregulate Egr-1 via ERK1/2 in PA smooth muscle cells; model to test impact of extracellular ROS in chronic hypoxia. PLoS One 6: e27531, 2011.

62. Iyoda T, Zhang F, Sun L, Hao F, Schmitz-Peiffer C, Xu X and Cui MZ: Lysophosphatidic acid induces early growth response-1 (Egr-1) protein expression via protein kinase CD-regulated extracellular signal-regulated kinase (ERK) and c-Jun N-termina kinase (JNK) activation in vascular smooth muscle cells. J Biol Chem 287: 22635-22642, 2012.

63. Wang C, Dostanic S, Servant N and Chalifour LE: Egr-1 negatively regulates expression of the sodium-calcium exchanger-1 in cardiomyocytes in vitro and in vivo. Cardiovasc Res 65: 187-194, 2005. 